\title{
Alterations of Human Placental Epidermal Growth Factor Receptor in Intrauterine Growth Retardation
}

\author{
C. Fondacci, ${ }^{\star 3}$ E. Alsat, * R. Gabriel, * Ph. Blot, ${ }^{\star}$ C. Nessmann, ${ }^{5}$ and D. Evain-Brion * \\ *Laboratoire de Physiopathologie du Développement, Ecole Normale Supérieure, 75230 Paris cedex 05, France; and ${ }^{\ddagger}$ Service de \\ Gynécologie-Obstétrique and ${ }^{\S}$ Laboratoire de Biologie du Développement et de la Reproduction, Hôpital R. Debré, 75019 Paris, France
}

\begin{abstract}
We studied human placental microvillous EGF receptor (EGFR) and its relationship with maternal and placental features in 14 cases of intrauterine growth retardation.

Placental EGFR phosphorylation was significantly decreased or absent in 12 cases of small for gestational age neonates, as shown by SDS-PAGE, autoradiography, and scanning analysis. Specific [ ${ }^{125}$ I] EGF binding and Scatchard plots of the binding data showed a decreased number of EGFR in 6 of the 12 cases, with a mean maximal binding capacity of $1.09 \pm 0.32$ $\mathrm{pmol} / \mathrm{mg}$ for high affinity sites (mean control value $=\mathbf{2 . 3 0} \pm \mathbf{0 . 2 3}$ $\mathrm{pmol} / \mathrm{mg}$ ). Most of the hypertensive women and smokers belonged to this subgroup. In three of the remaining six cases of small gestational age placentas with low EGFR phosphorylation, there was no maternal pathology or significant parenchymatous placental lesions. Five showed a 175-kD EGFR species when probed by [ $\left.{ }^{125} I\right]$ EGF cross-linking and Western blotting with RK2 and C-Term, two polyclonal anti-EGFR antibodies, suggesting abnormal transduction of the EGF-induced signal. The sixth placenta yielded a single 145-kD EGFR band consistent with an abnormal EGFR structure; Western blot analysis showed no immunoreactive band.

In conclusion, maternal and placental pathologies in intrauterine growth retardation are associated with various alterations of placental EGFR, pointing out the importance of EGFR ligands in the regulatory pathway of placental anf fetal growth. (J. Clin. Invest. 1994. 93:1149-1155.) Key words: epidermal growth factor receptor - fetal growth - intrauterine growth retardation $\bullet$ tyrosine kinase activity
\end{abstract}

\section{Introduction}

EGF is a multifunctional 53-amino acid peptide factor first known for its mitogenic action on epidermal and mesodermal cells (1). Several lines of evidence point to a prominent role of EGF in human placental growth and function. In humans, EGF is involved in embryonal implantation (2), stimulates syncytiotrophoblast differentiation in vitro (3), and modulates placental endocrine functions (3-6).

Address correspondence and reprint requests to Dr. C. Fondacci, Laboratoire de Physiopathologie du Développement, CNRS-URA 1337, ENS, 46 rue d'Ulm, 75230 Paris cedex 05, France.

Received for publication 21 May 1993 and in revised form.

J. Clin. Invest.

(C) The American Society for Clinical Investigation, Inc.

0021-9738/94/03/1149/07 \$2.00

Volume 93, March 1994, 1149-1155
The effects of EGF on target cells are mediated by the EGF receptor (EGFR), ${ }^{1}$ a transmembrane glycoprotein of $170 \mathrm{kD}$. Binding of EGF stimulates the receptor intracellular tyrosine kinase domain, which induces the phosphorylation of three tyrosine residues located on the $\mathrm{COOH}$-terminal region. This autophosphorylation process is required for the transmission of the EGF message to the cell and the control of cell division and differentiation (reviewed in reference 7).

EGFR is strongly expressed in the human placenta and its expression is modulated in various physiological conditions. An increase in EGF receptor numbers occurs during placental ontogenesis (8-10), syncytiotrophoblast formation in vitro (11), and after treatment of trophoblast cells with polypeptide hormones such as PTH (12).

Throughout gestation, EGFR is expressed predominantly on the apical microvillous plasma membrane of the syncytiotrophoblast $(13,14)$, which is a multifunctional tissue in contact with the maternal blood; the syncytiotrophoblast supports materno-fetal exchanges and secretes peptide and steroid hormones $(15,16)$.

Interestingly, alterations of human placental EGFR have been described in pathological and high risk pregnancies; these include decreased tyrosine kinase activity in smokers (17) and a loss of EGF binding sites in cases of intrauterine growth retardation (IUGR) (18). Few studies have been done in the latter setting.

Intrauterine growth retardation occurs in 3-5\% of pregnancies (19) and is a major risk factor for perinatal mortality and morbidity (20-22). Neonates with IUGR are highly heterogeneous: fetal chromosome disorders, maternal hypertension, drug addiction, and smoking are considered as strong risk factors for IUGR (23-24), but the possible relationship between maternal factors, IUGR, placental abnormalities, and EGFR alterations has not been examined.

To characterize EGFR in IUGR placentas and to improve our understanding of IUGR, we undertook a prospective study of 14 third trimester placentas corresponding to small for gestational age (SGA) neonates, analyzing clinical maternal and neonatal features, the histopathological aspect of the placentas, and the biochemical nature of placental EGFR.

\section{Methods}

Recruitment. Pregnant women were recruited at the Hôpital Robert Debré (Paris, France) when they came for delivery or antenatal testing.

1. Abbreviations used in this paper: AGA, appropriate for gestational age; $B_{\max }$, maximal binding capacity; EGFR, epidermal growth factor receptor; IUGR, intrauterine growth retardation; SGA, small for gestational age. 
They were included in the study at delivery if birthweight was below the third percentile on Leroy's chart (25). Gestational age was determined from the last menstrual period, serial ultrasound examinations, and birth characteristics. The study was approved by the regional ethics committee.

Clinical findings. The mothers' clinical and obstetrical histories and the neonates' clinical characteristics were recorded respectively by the obstetricians and pediatricians, respectively.

Placental examination and sampling. 14 placentas (P1-P14) from IUGR singletons were carefully examined. The mean gestational age was 36.3 wk. Placentas from six healthy women with uncomplicated singleton pregnancies, term delivery, and appropriate for gestational age (AGA) infants were used as controls.

Placentas were examined according to Benirschke and Kaufmann (26), with macroscopic descriptions of the shapes and cords, parenchymal aspects, and the type of lesions, when present. Three samples for histologic examination were included in paraffin and stained with haematoxylin-eosin. Fresh tissue devoid of lesions was immediately treated for biochemical studies.

Placental biochemical study. Anti-EGFR antibodies were a generous gift from Françoise Bellot (Rorer Technology Inc., King of Prussia, PA). Two polyclonal antibodies were used for Western blot analysis: RK2, which binds to an intracellular peptide near the kinase domain, and $\mathrm{C}$-Term, which recognizes an intracellular $\mathrm{COOH}$-terminal peptide. EGFR was immunoprecipitated with a monoclonal antibody (M108) raised against an EGFR extracellular peptide.

Preparation of microvillous plasma membrane fraction. Microvillienriched plasma membranes were purified from fresh placentas immediately after collection according to the method of Alsat et al. (27). Briefly, placental tissue was washed and minced in calcium- and magnesium-free ice-cold PBS, pH 7.4, and dissected into small pieces free of amnion, connective tissue, and blood clots. Microvillous plasma membranes were isolated from the washed tissue by gentle stirring with a magnetic stirrer in $50 \mathrm{ml}$ of ice-cold saline buffer for $30 \mathrm{~min}$ at $4^{\circ} \mathrm{C}$, then filtered through four layers of cheese cloth. The filtrate was then centrifuged at $800 \mathrm{~g}$ for $10 \mathrm{~min}$ at $4^{\circ} \mathrm{C}$. Microvillous fractions were pelleted by centrifugation of the supernatant at $50,000 \mathrm{~g}$ for $30 \mathrm{~min}$ at $4^{\circ} \mathrm{C}$. After two washes in the same chilled medium, the pellet was resuspended in $150 \mu \mathrm{l}$ of $20 \mathrm{mM}$ Tris $\mathrm{HCl}$ ( $\mathrm{pH} \mathrm{7.4),50} \mathrm{mM} \mathrm{NaCl}, 1$ $\mathrm{mM} \mathrm{CaCl}$ and $2 \mathrm{mM} \mathrm{MgCl}$, frozen in liquid nitrogen, and kept at $-80^{\circ} \mathrm{C}$ until use.

The purity of the samples was determined by colorimetric evaluation of membrane alkaline phosphatase activity (alkaline phosphatase kit; Biomérieux, Craponne, France). Protein was determined by a fluorometric assay with BSA as standard (28).

EGF receptor autophosphorylation. Phosphorylation was determined according to Rao et al. (13). Briefly, $50 \mu \mathrm{g}$ of microvillous membrane protein was incubated for $10 \mathrm{~min}$ at $4^{\circ} \mathrm{C}$ in a final volume of 50 $\mu \mathrm{l}$ of $16 \mathrm{mM}$ Hepes ( $\mathrm{pH} 7.4$ ), $0.1 \mathrm{mM}$ adenyl-5'-yl-iminodiphosphate (Sigma Immunochemicals, St. Louis, $\mathrm{MO}$ ), $1 \mathrm{mM} \mathrm{MnCl}_{2}$ and $0.1 \%$ BSA in the presence or absence of $100 \mathrm{nM} \mathrm{EGF}$ and $5 \mathrm{mM}\left[\gamma^{32} \mathrm{P}\right] \mathrm{ATP}$ (3,000 Ci/mmol; Amersham Corp., Arlington Heights, IL). Kinase activity was abrogated by addition of an equal volume of Laemmli buffer and heating at $100^{\circ} \mathrm{C}$ for $1 \mathrm{~min}$; aliquots were analyzed by $7.5 \%$ SDS-PAGE (29) and autoradiography. The intensity of the labeled protein bands was quantified by laser scanning densitometry (Hermes program, one-dimensional analysis module).

Labeled protein was precipitated with the monoclonal antibody M108 (ascitic fluid). Briefly, $100 \mu \mathrm{g}$ of phosphorylated villous protein was incubated for $1 \mathrm{~h}$ at $4^{\circ} \mathrm{C}$ with $5 \mu \mathrm{l}$ of antibody, $50 \mu \mathrm{l}$ of protein A-Sepharose 10\% (CL-4B; Pharmacia Fine Chemicals, Piscataway, $\mathrm{NJ}$ ) in $500 \mu \mathrm{l}$ of $50 \mathrm{mM}$ Tris, pH 7.5, $150 \mathrm{mM} \mathrm{NaCl}, 0.1 \%$ SDS, $1 \%$ Triton X-100 (buffer A). After centrifugation, the pellets were rinsed several times in buffer $A$ and remaining protein was analyzed by SDSPAGE after extended boiling.

Insulin receptor phosphorylation. Glycoprotein receptors were purified from solubilized placental membranes by agarose-bound wheat germ agglutinin chromatography (Pharmacia Fine Chemicals) as described by Lowe et al. (30). It was concentrated (Centricon 30; Amicon Corp., Danvers, MA) and insulin receptor phosphorylation was performed as described above for EGFR using $70 \mu \mathrm{g}$ of lectin-purified glycoprotein after preincubation in the presence or absence of $0.1 \mathrm{mM}$ porcine insulin.

Tyrosine kinase assay: angiotensin II phosphorylation. The EGFR tyrosine kinase assay was performed by a modification of the method of Honegger et al. (31). Briefly, solubilized microvillous protein was preincubated in the presence or absence of $100 \mathrm{nM}$ EGF for $10 \mathrm{~min}$ at $24^{\circ} \mathrm{C}$. Phosphorylation of $2 \mathrm{mM}\left[\mathrm{Val}^{5}\right.$ ] angiotensin II (Sigma Immunochemicals) was performed with $1 \mathrm{mg}$ of protein in the presence of 5 $\mathrm{mM}\left[\gamma^{32} \mathrm{P}\right] \mathrm{ATP}$, and $4 \mathrm{mM} \mathrm{MnCl}{ }_{2}$ for $10 \mathrm{~min}$ at $4^{\circ} \mathrm{C}$. The reaction was stopped with $4 \%$ TCA in the presence of $1 \%$ BSA for $10 \mathrm{~min}$ on ice. After centrifugation, $60 \mu \mathrm{l}$ of supernatant was layered on $2-\mathrm{cm}^{2}$ phosphocellulose squares (P81; Whatman Inc., Clifton, $\mathrm{NJ}$ ) and rinsed in $75 \mathrm{mM}$ phosphoric acid; radioactivity was counted in a $\beta$ counter (LKB Instruments Inc., Bromma, Sweden).

$\left[{ }^{125}\right.$ I] EGF binding study and Scatchard analysis. [ ${ }^{125}$ I]EGF binding studies were performed by a modification of the method of Alsat et al. (12). The conditions were determined by incubating 0-40 $\mu \mathrm{g}$ of microvillous membrane protein for $2 \mathrm{~h}$ at $24^{\circ} \mathrm{C}$ in the presence of 0.25 nM [ ${ }^{125}$ I]EGF (914-1,295 Ci/mmol; Amersham Corp.) with or without an excess of unlabeled human $\operatorname{EGF}(0.5 \mu \mathrm{M})$; the incubation medium was composed of $50 \mathrm{mM}$ Tris $\mathrm{HCl}, 1 \mathrm{mM} \mathrm{CaCl}, 0.2 \% \mathrm{BSA}, \mathrm{pH}$ 7.5. The membranes were then collected in microcentrifuge tubes (Airfuge) by centrifugation at $100,000 \mathrm{~g}$ for $20 \mathrm{~min}$ at $4^{\circ} \mathrm{C}$ (LP $42.2 \mathrm{TI}$ rotor; Beckman Instruments, Inc., Fullerton, CA). The pellets were rinsed twice and counted in a $\gamma$ counter (LKB Instruments Inc.) with an average counting efficiency of $75 \%$. Each microvillous preparation was assayed in triplicate and the specific binding was obtained from the difference of $\left[{ }^{125} I\right] E G F$ binding in the absence and presence of unlabeled EGF. Nonspecific binding in all experiments was $<10 \%$ of total binding.

The characteristics of EGF binding were assessed by drawing Scatchard plots of bound and free EGF at equilibrium from the EGF displacement data (32). Briefly, $5 \mu \mathrm{g}$ of protein was incubated in the presence of $0.25 \mathrm{nM}$ [ $\left.{ }^{125} \mathrm{I}\right] \mathrm{EGF}$ and $0-50 \mathrm{nM}$ of unlabeled EGF. All assays were carried out in triplicate. Maximal binding capacity $\left(B_{\max }\right)$ values were expressed in fentomoles of [ $\left.{ }^{125} \mathrm{I}\right] \mathrm{EGF}$ bound per milligram of protein, and $K_{\mathrm{d}}$ values were determined from the slope according to Rosenthal (33).

Affinity cross-linking of EGFR. Covalent cross-linking of [ $\left.{ }^{125} \mathrm{I}\right]-$ EGF to membrane EGFR was performed as previously described (34) using dissucinimidyl suberate (Pierce Chemical Co., Rockford, IL) as cross-linker reagent and $50 \mu \mathrm{g}$ of membrane protein; protein was then subjected to $7.5 \%$ SDS PAGE and autoradiography.

Western blotting. $50 \mu \mathrm{g}$ of placental microvillous protein was submitted to 7.5\% SDS-PAGE (miniProtean II; Bio Rad Laboratories, Richmond, CA). Protein was then transferred to nitrocellulose sheets (Millipore Corp., Bedford, MA) using a semidry apparatus (Trans-blot $\mathrm{SD}$; Bio Rad Laboratories). Transfer was performed in $39 \mathrm{mM}$ Tris, 48 $\mathrm{mM}$ glycine, $20 \%$ methanol ( $\mathrm{vol} / \mathrm{vol}$ ), and $1.3 \mathrm{mM}$ SDS at $\mathrm{pH} 8.5$ for $75 \mathrm{~min}$. The nitrocellulose sheets were then washed in $10 \mathrm{mM}$ Tris, 150 $\mathrm{mM} \mathrm{NaCl}, 0.05 \%$ Triton X-100, $\mathrm{pH} 7.4$ (TBS), and incubated for $12 \mathrm{~h}$ at $4{ }^{\circ} \mathrm{C}$ with the anti-EGF receptor polyclonal antibodies RK2 and CTerm (dilution $=1: 200$ ) or nonimmune rabbit serum IgG in 5\% BSATBS. The linked antibodies were revealed with iodinated protein $A$ (> $30 \mathrm{mCi} / \mathrm{mg}$; Amersham Corp.) and autoradiography.

Statistical analysis. Differences between mean values were compared by Student's $t$ test. The results are given as the mean $\pm \mathrm{SD} ; P$ $\leq 0.01$ were considered significant.

\section{Results}

Clinical observations and placental examination. The clinical and placental findings are summarized in Table I. Five cases of 
Table I. SGA Placentas: Maternal Clinical Findings and Placental Pathology

\begin{tabular}{|c|c|c|c|c|c|c|}
\hline \multirow[b]{2}{*}{ Cases } & \multicolumn{3}{|c|}{ Maternal background } & \multicolumn{3}{|c|}{ Placental pathology } \\
\hline & HTA/Tox & Smoking & Other & $\begin{array}{l}\text { Abnormal } \\
\text { conf/cord }\end{array}$ & $\begin{array}{l}\text { Vascular } \\
\text { lesion }\end{array}$ & Other \\
\hline P1 & $-\quad-$ & - & & - & - & \\
\hline P2 & $-\quad+$ & - & & - & + & \\
\hline P3 & $-\quad-$ & + & & - & - & VUE \\
\hline P4 & $-\quad-$ & + & & + & - & \\
\hline P5 & $-\quad-$ & - & & + & - & \\
\hline P6 & +- & + & & - & + & $\mathrm{BDH}$ \\
\hline P7 & $-\quad+$ & + & & - & + & \\
\hline P8 & $-\quad+$ & - & & - & + & \\
\hline P9 & $-\quad-$ & + & Anorexia & + & + & VUE \\
\hline $\mathrm{P} 10$ & $-\quad-$ & - & & - & + & \\
\hline P11 & $-\quad+$ & + & & - & + & \\
\hline $\mathrm{P} 12$ & $-\quad-$ & - & & - & - & \\
\hline P13 & $-\quad-$ & - & & + & - & \\
\hline P14 & $-\quad-$ & - & & - & - & \\
\hline
\end{tabular}

Conf/cord, abnormal configuration of the placenta and/or abnormal cord; BDH, basal decidual haematoma; HTA, maternal hypertension; Tox, toxemia; VUE, villitis of unknown aetiology.

maternal hypertension were observed, with one case of decidual haematoma-complicated hypertension (P6) and four of toxemia (P2, P7-8, and P11). Three women smoked 10-20 cigarettes per day ( $\mathrm{P} 3, \mathrm{P} 6$, and $\mathrm{P} 11)$ throughout pregnancy, and three (P4, P7, and P9) smoked 3-10 cigarettes per day. One woman (P9) was anorexic. In the other six cases (P1, P5, $\mathrm{P} 10$, and P12-14), the clinical findings were unremarkable.

Cord or minor placental shape abnormalities were found in four cases (P4, P5, P9, and P13). Seven placental infarcts were found, including all the cases of maternal hypertension. Chronic villitis was observed in two placentas, both from smokers ( $\mathrm{P} 3$ and P9).

No potential causes of IUGR or placental abnormalities were observed in three cases (P1, P12, and P14).

EGFR tyrosine kinase activity. In AGA microvillous membranes, EGF specifically induced phosphorylation of two proteins (Fig. $1 A$, lane $A$ ): a $170-\mathrm{kD}$ species identified as EGFR by immunoprecipitation with a specific anti-EGFR monoclonal antibody (Fig. $1 \mathrm{~B}$ ) and a 35-kD species corresponding to lipocortine I, a substrate of EGFR tyrosine kinase $(35,36)$.

SGA microvillous membranes displayed low (Fig. $1 A$, lane $B$ ) or undetectable EGFR autophosphorylation (Fig. $1 A$, lane $C)$. Quantitative values for EGFR autophosphorylation obtained by scanning analysis are shown in Fig. 2. EGFR tyrosine kinase activity in 12 SGA placental membranes was below the mean value obtained in the six control placentas (mean \pm SD $=1.55 \pm 0.6 \mathrm{OD}$ ). Little if any EGFR phosphorylation was observed in nine cases ( P3, P5-11, and P14), while the remaining three showed reduced amounts (P4, P12, and P13). EGFR phosphorylation was in the lower range of normal values in $\mathrm{P} 1$ and normal in P2.

EGFR tyrosine kinase activity was further investigated by EGF-dependent phosphorylation of the exogenous EGFR substrate $\left[\mathrm{Val}^{5}\right.$ ] angiotensin II. AGA microvillous protein induced

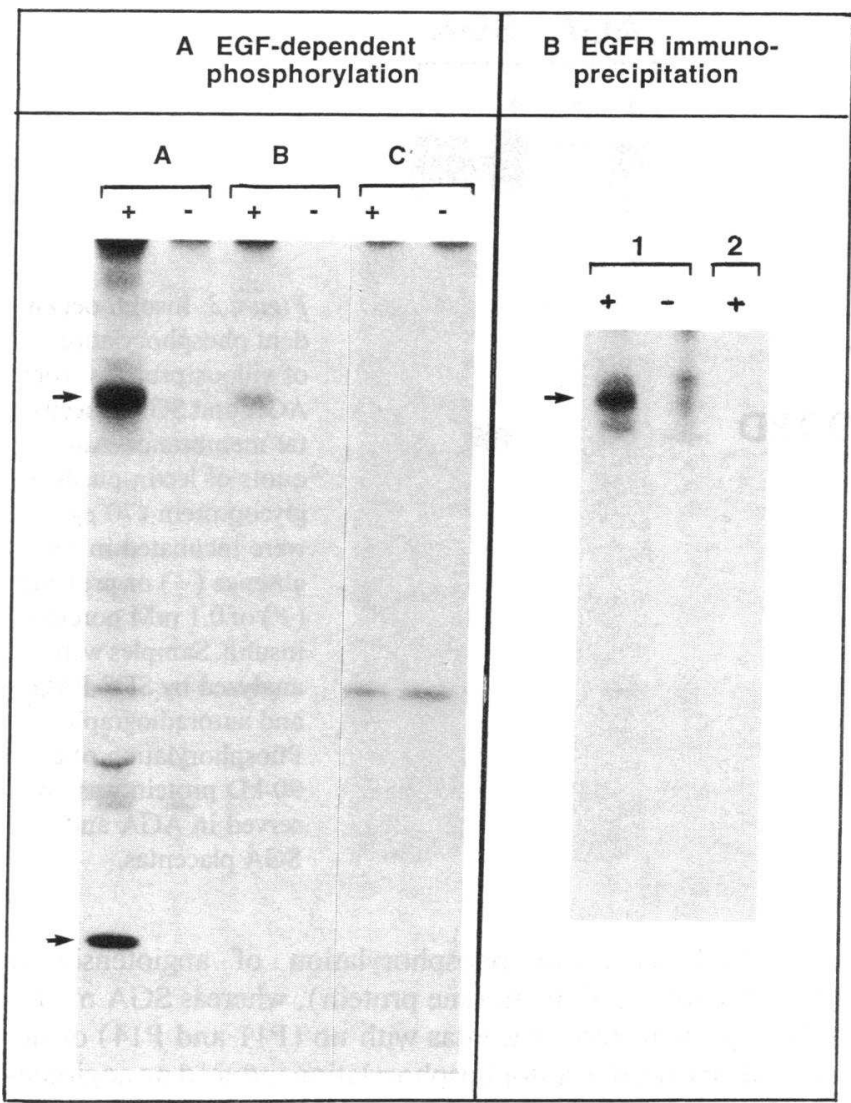

Figure 1. EGF-dependent phosphorylation of AGA and SGA placental microvillous proteins. Aliquots of microvillous proteins $(50 \mu \mathrm{g})$ from AGA (lane $A$ ) and SGA (lanes $B$ and $C$ ) placentas were incubated with $\left[\gamma^{32} \mathrm{P}\right] \mathrm{ATP}$ in the absence $(-)$ or presence $(+)$ of 100 nM EGF. Phosphorylated proteins were analyzed by SDS-PAGE either directly $(A)$ or after immunoprecipitation $(B)$ with monoclonal antibody M108 against EGFR (lane 1 ) or nonimmune serum (lane 2 ) in the absence ( - ) or presence (+) of $100 \mathrm{nM}$ EGF. The gel was submitted to autoradiography as described in Methods.

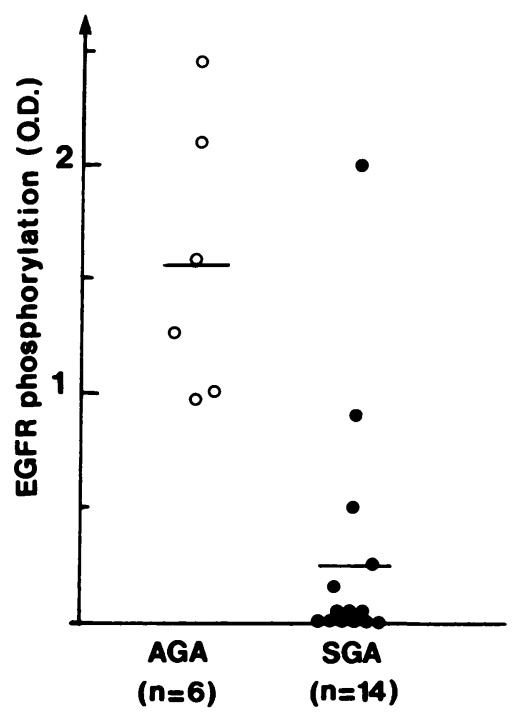

Figure 2. Autoradiograph scanning analysis of EGFR autophosphorylation. The mean value for AGA placen$\operatorname{tas}(n=6)$ was $1.55 \pm 0.6$ (OD units). 


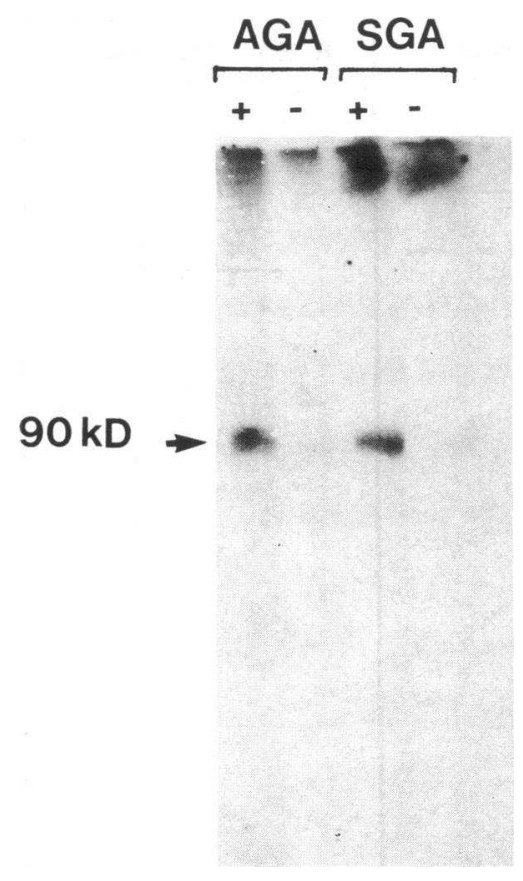

Figure 3. Insulin-dependent phosphorylation of villous proteins from AGA and SGA placental membranes. Aliquots of lectin-purified glycoprotein $(70 \mu \mathrm{g})$ were incubated in the absence $(-)$ or presence $(+)$ of $0.1 \mathrm{mM}$ porcine insulin. Samples were analyzed by SDS-PAGE and autoradiography. Phosphorylation of a 90-kD protein was observed in AGA and SGA placentas.

clear EGF-dependent phosphorylation of angiotensin II $(11,300 \mathrm{cpm} / \mu \mathrm{g}$ of membrane protein $)$, whereas SGA microvillous protein from placentas with no (P11 and P14) or decreased (P4) EGFR autophosphorylation induced no angiotensin II phosphorylation or a 50\% decrease, respectively, when compared to the control values. These results suggest that the loss of EGFR autophosphorylation is related to defective EGFR tyrosine kinase activity.

The specificity of the EGFR tyrosine kinase alteration was checked by performing an insulin-receptor autophosphorylation assay with lectin-purified membrane protein from AGA and SGA placentas. As shown in Fig. 3, insulin catalyzed the phosphorylation of a single $90-\mathrm{kD}$ membrane protein. In SGA placentas, this insulin-dependent phosphorylation was comparable to that in pregnancies with AGA newborns, showing the EGFR specificity of the tyrosine kinase activity alteration in SGA placentas.

$\left[{ }^{125} I\right] E G F$ binding studies and Scatchard analysis. To check whether the decrease in tyrosine kinase activity observed in the microvilli from 12 SGA placentas was caused by a de- crease in the number of EGFR, we undertook [ ${ }^{125}$ I]EGF binding studies comparatively with AGA placental membranes. Binding equilibrium was reached within $2 \mathrm{~h}$ at room temperature. A linear relationship was observed between specific [ $\left.{ }^{125} \mathrm{I}\right]-$ EGF binding and increasing amounts of placental microvillous membranes $\leq 10 \mu \mathrm{g}$ protein. In control placentas, Scatchard plots of [ ${ }^{125}$ I $]$ EGF binding were curvilinear, indicating the presence of two classes of binding site (Fig. 4). $K_{\mathrm{d}}$ and $B_{\max }$ of EGF binding for AGA placentas are reported in Table II. In SGA placental membranes, $B_{\max }$ values of EGF binding were within the normal range in six cases (Fig. $4 A$, P9-P14, and Table II, SGA, $A)$ and significantly decreased $(P<0.002)$ in the other six cases ( Fig. $4 B$, P3-P8, and Table II, SGA, $B$ ). The affinities of the EGF binding sites were not modified.

Covalent cross-linking of $\left[{ }^{125} I\right] E G F$. Analysis by SDSPAGE and autoradiography of placental EGFR, after [ $\left.{ }^{125} \mathrm{I}\right]-$ EGF cross-linking, yielded one labeled 175-kD protein in AGA placentas (Fig. 5, lane 1). The labeling was abolished when the binding of $\left[{ }^{125} \mathrm{I}\right] \mathrm{EGF}$ was performed with an excess of unlabeled EGF (lanes 2, 4, and 6). In all but one (P14) of the SGA placentas, a $175-\mathrm{kD}$ protein was observed. The labeling of this 175-kD EGFR was decreased in the six placentas with a small number of microvillous EGFR (lane 3); it was increased in P2, and comparable to controls in the other five. In the SGA placenta P14, a single $145-\mathrm{kD}$ membrane protein, was labeled (lane 5).

Immunoblotting of EGFR. Western blots were performed with two polyclonal antibodies (RK2 and C-Term) prepared against denatured human EGFR protein (37). Fig. 6 shows a representative autoradiograph of the $170-\mathrm{kD}$ microvillous EGFR protein detected with RK2 and C-Term antibodies in AGA placentas (Fig. 6, lanes $A$ and $D$ ). A similar pattern was observed in the SGA placentas (except P14), with decreased immunodetection of EGFR in the six cases with a small number of EGF binding sites (Fig. 6, lanes $B$ and $E$ ). EGFR was not detected in placenta P14 microvilli, with either C-Term or RK2 (Fig. 6, lanes $C$ and $F$ ).

The results of biochemical and immunochemical studies are summarized in Table III.

\section{Discussion}

Despite the prominent role of EGF in placental growth and function (38), few studies have been undertaken on placentas

Table II. $K_{d}$ and $B_{\max }$ of High and Low Affinity EGF Binding Sites in Placental Microvilli from $A G A$ and $S G A ;$ Results are Expressed in Means $\pm S D$

\begin{tabular}{|c|c|c|c|c|c|}
\hline & & \multicolumn{2}{|c|}{ High affinity binding sites } & \multicolumn{2}{|c|}{ Low affinity binding sites } \\
\hline & & $K_{\mathrm{d}}$ & $B_{\max }$ & $K_{\mathrm{d}}$ & $B_{\max }$ \\
\hline & & $10^{-10}$ mollliter & pmol/mg & $10^{-9} \mathrm{~mol} / \mathrm{liter}$ & pmol/mg \\
\hline \multirow{2}{*}{$\begin{array}{l}\text { AGA } \\
(n=6)\end{array}$} & & $0.80 \pm 0.09$ & $2.30 \pm 0.23$ & $0.11 \pm 0.05$ & $6.86 \pm 2.62$ \\
\hline & $\begin{array}{l}\mathrm{A} \\
(n=6)\end{array}$ & $1.12 \pm 0.60$ & $2.93 \pm 0.60$ & $0.19 \pm 0.05$ & $6.80 \pm 1.90$ \\
\hline SGA & $\begin{array}{l}\text { B } \\
(n=6)\end{array}$ & $1.07 \pm 0.24$ & $1.09 \pm 0.32$ & $0.19 \pm 0.09$ & $2.43 \pm 0.08$ \\
\hline
\end{tabular}



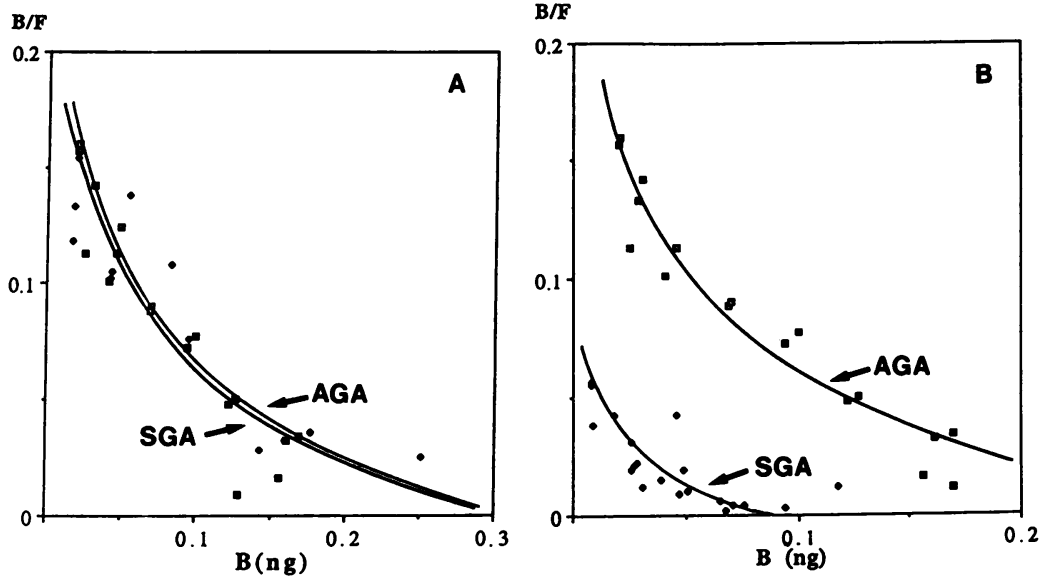

Figure 4. Scatchard analysis of EGF binding to AGA and SGA microvillous membranes. Aliquots of protein $(5 \mu \mathrm{g})$ were incubated in the presence of $0.25 \mathrm{nM}$ [ ${ }^{125}$ I]EGF and 0-50 nM of unlabeled EGF. Representative experiments show in $(A)$ no change in the number of EGF binding sites in SGA placentas and in $(B)$ a decreased number of EGF binding sites. The data were plotted according to Scatchard. B, bound EFG; F, free EFG. from IUGR pregnancies and no correlation has been sought with maternal and placental characteristics.

This study of 14 cases of IUGR shows an association between IUGR and altered placental EGFR activity, as demonstrated by a marked decrease in tyrosine kinase activity. 12 of the 14 SGA placentas displayed reduced or absent EGFR autophosphorylation. A specific loss of placental EGFR tyrosine kinase activity has been observed by Wang et al. (17) in pooled membrane fractions from smokers, but Scatchard analysis of EGF binding was not performed, and it was not stated whether smoking was associated with IUGR. All the placental membranes from the smokers with SGA neonates in our study showed impaired EGFR phosphorylation.

Various factors may result in impaired EGFR phosphorylation, such as a decreased number of EGF binding sites, unbalanced phosphatase activity, abnormal EGFR structure, and protein degradation. As placental membranes show phosphatase activity (39-40), assays were performed with AGA and SGA microvilli to determine whether a failure to detect EGFR kinase activity was caused by high tyrosine phosphatase activity; mixing SGA membranes with no EGFR phosphorylation and AGA membranes did not modify the pattern of EGF-dependent phosphorylated proteins in AGA membranes. Furthermore, the addition of a tyrosine phosphatase inhibitor, sodium vanadate, did not increase EGFR autophosphorylation in

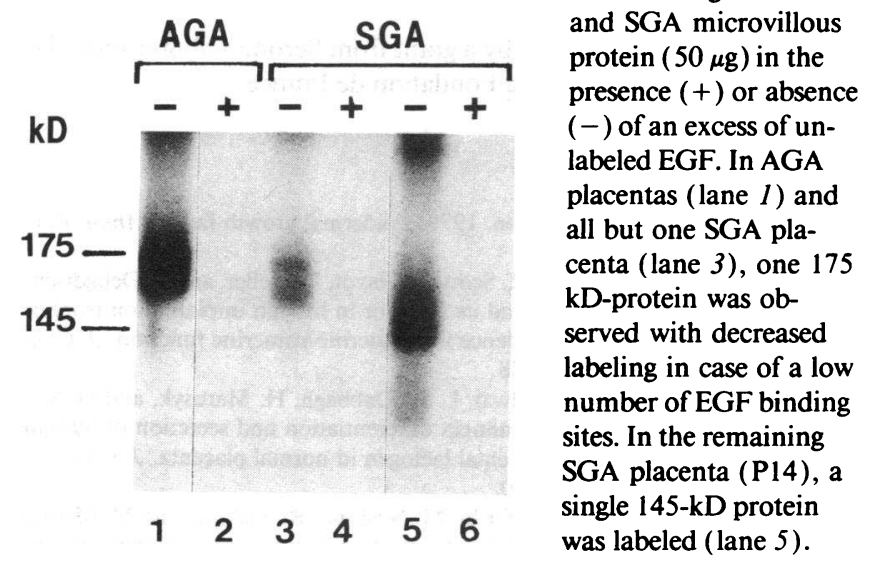

AGA or SGA membranes (data not shown). However, specific investigations of tyrosine phosphatase activity in IUGR placentas would be required to rule out a possible dysregulation of these enzymes in SGA placenta membranes.

The alteration of EGF-dependent tyrosine kinase activity appeared to be specific, as insulin autophosphorylation was preserved in SGA placental membranes that showed decreased EGFR autophosphorylation.

Impaired EGFR autophosphorylation may be related to partial proteolytic degradation. Previous works have shown that partial EGFR proteolysis cleaves the intracellular domain of the receptor and removes tyrosine phosphorylation sites but not the tyrosine kinase domain (41); proteolysis-damaged EGF receptors are thus expected to show decreased autophosphorylation but unchanged phosphorylation of exogenous substrates such as angiotensin II. This was not the case of the SGA membranes: decreased or absent EGFR autophosphorylation was associated with a decrease in or absence of angiotensin II phosphorylation in every case. This suggests that, in these

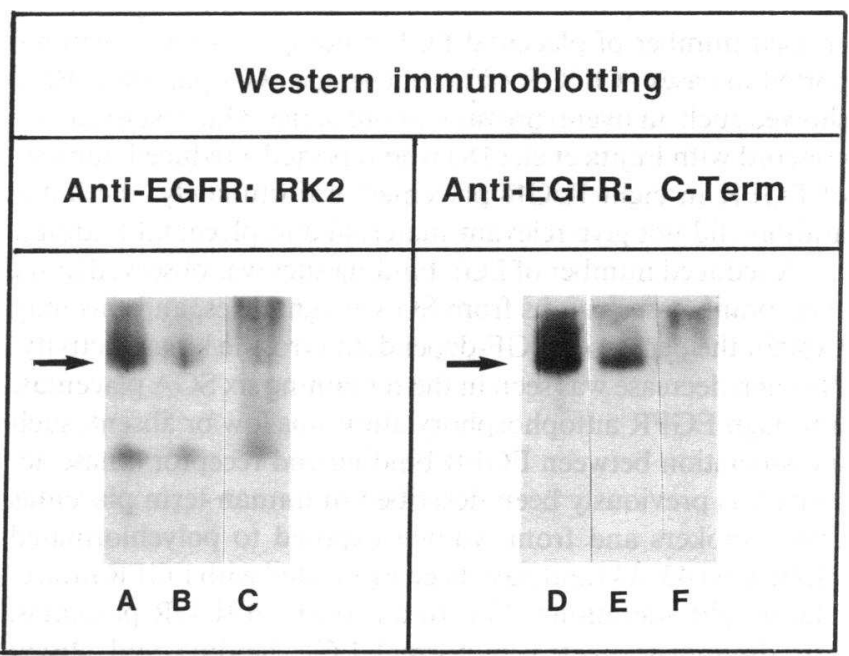

Figure 6. Western blotting was performed on AGA and SGA microvillous proteins with two anti-EGFR polyclonal antibodies, RK2 and $C$-Term. The same pattern was observed in AGA placentas (lanes $A$ and $D$ ) and SGA placentas (lanes $B$ and $E$ ), except for a lower signal when the number of microvillous EGFR was reduced. In SGA placenta P14, neither RK2 nor C-Term bound to membrane proteins (lanes $C$ and $F$ ). 
Table III. Biochemical Characteristics of EGFR in SGA Placentas

\begin{tabular}{lcccc}
\hline Cases & Phosphorylation* & $\begin{array}{c}\text { Binding }^{*} \\
\left(\boldsymbol{B}_{\max }\right)\end{array}$ & $\begin{array}{c}\text { Mol wt } \\
(\mathrm{kD})\end{array}$ & $\begin{array}{c}\text { Western } \\
\text { blotting }\end{array}$ \\
\hline P1 & + & $\mathrm{N}$ & 175 & + \\
P2 & + & $\mathrm{N}$ & 175 & + \\
P3 & $\searrow$ & $\searrow$ & 175 & + \\
P4 & $\searrow$ & $\searrow$ & 175 & + \\
P5 & $\searrow$ & $\searrow$ & 175 & + \\
P6 & $\searrow$ & $\searrow$ & 175 & + \\
P7 & $\searrow$ & $\searrow$ & 175 & + \\
P8 & $\searrow$ & $\searrow$ & 175 & + \\
P9 & $\searrow$ & $\mathrm{N}$ & 175 & + \\
P11 & $\searrow$ & $\mathrm{N}$ & 175 & + \\
P10 & $\searrow$ & $\mathrm{N}$ & 175 & + \\
P12 & $\searrow$ & $\mathrm{N}$ & 175 & + \\
P13 & $\searrow$ & $\mathrm{N}$ & 175 & + \\
P14 & $\searrow$ & $\mathrm{N}$ & 145 & - \\
& & & & + \\
\hline
\end{tabular}

* EGF-dependent autophosphorylation of the receptor (+ denotes normal range by scanning analysis and $\searrow$ denotes low or undetectable EGFR phosphorylation). ${ }^{\ddagger}$ Number of EGF binding sites $\left(B_{\max }\right)$ as assessed by Scatchard plots of bound and free EGF at equilibrium from displacement data ( $\mathrm{N}$ denotes normal range and $\backslash$ denotes decreased number of EGF binding sites). ${ }^{\S}$ Molecular weight of microvillous EGFR as determined by [ ${ }^{125}$ I]EGF cross-linking. "Immunoblot analysis of EGFR using two polyclonal antibodies against EGFR (RK2 and C-Term); recognition $(+)$ or no recognition $(-)$ by both RK2 and C-Term.

cases, an abnormality of EGFR tyrosine kinase domain or function is involved in the decrease of EGFR autophosphorylation.

Scatchard analysis of binding distinguished two major types of SGA placentas: those with a decreased number of EGF binding sites and those with an unchanged number of binding sites when compared to control placentas. Although an increased number of placental EGF binding sites have been reported in cases of IUGR (42), one single SGA placenta (P2), showed such an overexpression in our series. Our results rather concord with Fujita et al. (18) who reported a reduced number of EGFR in eight IUGR placentas; unfortunately, the latter authors did not give relevant maternal and placental findings.

A reduced number of EGF binding sites was observed in six membrane preparations from SGA pregnancies, and this may explain the decreased EGF-dependent tyrosine kinase activity. No such decrease was seen in the remaining six SGA placentas, although EGFR autophosphorylation was low or absent; such a dissociation between EGFR binding and receptor kinase activity has previously been described in human term placentas from smokers and from women exposed to polychlorinated biphenyls $(43,44)$ and have been associated with EGFR molecular weight alterations (17). In our study of IUGR placentas, this discrepancy between normal EGF binding and absent EGFR tyrosine kinase activity was associated in five cases with a normal EGFR molecular weight and immunochemical recognition comparable to that in AGA placentas. A receptor mutation could explain the impaired signal transduction and loss of EGFR autophosphorylation in these five placentas $(45,46)$. In one case (P14), the EGFR had normal binding capacity but no tyrosine kinase activity; its molecular weight (145 kD) was abnormal and its $\mathrm{COOH}$-terminal intracellular domain was not labeled by a specific antibody, suggesting that it was a truncated form. Such an alteration of EGFR molecular weight has been described in placentas from smokers, but additional investigations of the receptor and protein sequencing would be required to sustain this hypothesis.

In our series of 14 placentas with IUGR, only one placenta (P2) from toxemic mother showed an increase in EGFR number $\left(B_{\max }=5.30 \mathrm{pmol} / \mathrm{mg}\right.$ protein $)$. Comparable results were previously described (42). However, it should be noticed that in this P2 placenta increase in EGFR number was not associated with a concomitant increase in tyrosine kinase activity, which remained in the normal range.

IUGR was not associated with maternal risk factors in about half the cases $(n=6)$, but abnormal placentas were observed in all cases but three, underlining the need to examine the placenta when evaluating IUGR. Maternal hypertension, a major cause of IUGR (24), was prevalent in the subgroup with reduced placental EGF binding site numbers, and as expected, was associated with placental infarcts $(47,48)$. However, vascular lesions were also observed in the absence of maternal hypertension, mainly in placentas with normal EGFR numbers. Two placentas showed signs of chronic villitis of unknown etiology, which has been described in cases of IUGR, but its significance is unclear (49). A long cord was the only abnormality in P13. No aetiology for IUGR was found three cases (P1, P12, and P14); $\sim 18 \%$ of cases of IUGR are considered "idiopathic" (50). Nevertheless, EGFR tyrosine kinase activity was impaired in two of the three (P12 and P14) and associated in P14 with an abnormal EGFR molecular weight.

In conclusion, IUGR is associated with various alterations of placental EGFR. Early EGFR dysfunction could be linked to inadequate trophoblast differentiation and impaired migration of extravillous cytotrophoblasts described in maternal toxemia $(51,52)$ and causing deficient perfusion of the intervillous space. Later in gestation, it may contribute to deficient villous syncytial metabolism. The impact of EGF receptor alterations on placental function remains to be determined.

\section{Acknowledgments}

We are grateful to the obstetric residents and pediatricians of Hôpital R. Debré for recruiting the patients, to Dr. Cochet (Institut National de la Santé et de la Recherche Médicale U244, Grenoble, France) for his advice, Dr. Donnadieu (Centre National de la Recherche Scientifique URA 1337, Paris), and Dr. Tarroux (Service de Bioinformatique, ENS, Paris) for their contributions to Scatchard analysis and gel scanning, respectively.

This work was supported by a grant from Serono Laboratories, the European community, and la Fondation de France.

\section{References}

1. Carpenter, G., and S. Cohen. 1979. Epidermal growth factor. Annu. Rev. Biochem. 48:193-216.

2. Hofmann, G., M. Drews, R. Scott, D. Navot, D. Heller, and L. Deligdisch. 1992. Epidermal growth factor and its receptor in human implantation trophoblast: immunohistochemical evidence for autocrine-paracrine function. J. Clin. Endocrinol. \& Metab. 74:981-988.

3. Morrish, D. W., D. Bhardwaj, L. K. Dabbagh, H. Marusyk, and O. Siy. 1987. Epidermal growth factor induces differentiation and secretion of human chorionic gonadotropin and placental lactogen in normal placenta. J. Clin. Endocrinol. \& Metab. 65:1282-1290.

4. Maruo, T., H. Matsuo, T. Oishi, M. Noshino, R. Nishino, and M. Mochizuki. 1987. Induction of differentiated trophoblast function by epidermal growth 
factor. Relation of immunohistochemically detected cellular epidermal growth factor receptors levels. J. Clin. Endocrinol. \& Metab. 64:744-750.

5. Maruo, T., H. Matsuo, K. Murata, and M. Mochizuki. 1992. Gestational age-dependent dual action of epidermal growth factor on human placenta early in gestation. J. Clin. Endocrinol. \& Metab. 75:1362-1367.

6. Barnea, E. R., D. Feldman, M. Kaplan, and D. W. Morrish. 1990. The dual effect of epidermal growth factor upon human chorionic gonadotropin secretion by the first trimester placenta in vitro. J. Clin. Endocrinol. \& Metab. 71:923-928.

7. Prigent, S. A., and N. R. Lemoine. 1992. The type I (EGFR-related) family of growth factor receptors and their ligands. Progress in Growth Factor Res. 4:19-24.

8. Carson, S. A., R. Chase, E. Ulep, A. Scommegna, and R. Benveniste. 1983. Ontogenesis and characteristics of epidermal growth factor receptors in human placenta. Am. J. Obstet. Gynecol. 147:932-939.

9. Chen, C-F., H. Kurachi, Y. Fujita, N. Terakawa, A. Miyake, and O. Tanizawa. 1988. Changes in epidermal growth factor receptor and its messenger ribonucleic acid levels in human placenta and isolated trophoblast cells during pregnancy. J. Clin. Endocrinol. \& Metab. 67:1171-1177.

10. Ilekis, J., B. C. Stark, and R. Benveniste. 1991. Expression of epidermal growth factor receptors at the mRNA and cell membrane levels in first trimester and term human placentae. In Trophoblast Research: Molecular biology and Cell Regulation of the Placenta. R. K. Miller and H. A. Thiede, editors. Verav Medical Publishers, Rochester, NY. 5 pp. 103-117.

11. Alsat, E., J. Haziza, and D. Evain-Brion. 1993. Increase in epidermal growth factor receptor and its messenger ribonucleic acid levels with differentiation of human trophoblast cells in culture. J. Cell. Physiol. 154:122-128.

12. Alsat, E., V. Mirlesse, C. Fondacci, M. Dodeur, and D. Evain-Brion. 1991 Parathyroid hormone increases epidermal growth factor receptors in cultured human trophoblastic cells from early and term placenta. J. Clin. Endocrinol. \& Metab. 73:288-295.

13. Rao, Ch. V., N. Ramani, N. Chegini, B. K. Stadig, F. R. Carman, P. G Woost, G. S. Schultz, and C. L. Cook. 1985. Topography of human placental receptor for epidermal growth factor. J. Biol. Chem. 260:1705-1710.

14. Kawagoe, K., J. Akiyama, T. Kawamoto, Y. Morishita, and S. Mori. 1990. Immunohistochemical demonstration of epidermal growth factor (EGF) receptors in normal human placental villi. Placenta. 11:7-15.

15. Albrecht, E. D., and G. Pepe. 1990. Placental steroid hormone biosynthesis in primate pregnancy. Endocr. Rev. 11:124-150.

16. Contractor, S. F. 1983. Metabolic and enzymatic activity of human trophoblast. In Biology of Trophoblast. Y. W. Loke and A. Whyte, editors. Elsevier/ North Holland, Amsterdam. 235-281.

17. Wang, S.-L., G. W. Lucier, R. B. Everson, G. I. Sunhara, and K. T. Shiverick. 1987. Smoking-related alterations in epidermal growth factor and insulin receptors in human placenta. Mol. Pharmacol. 34:265-271.

18. Fujita, Y., H. Kurachi, K. Morishige, K. Amemiya, N. Terakawa, A. Miyake, and O. Tanizawa. 1991. Decrease in epidermal growth factor receptor and its messenger ribonucleic acid levels in intrauterine growth-retardated and diabetes mellitus-complicated pregnancies. J. Clin. Endocrinol. \& Metab. 72:1340-1345.

19. Levi, S. 1986. Retard de croissance intra-utérin: critique des moyens de mesure de la croissance foetale. In Retard de Croissance Intra-utérin: Période Anténatale. (1er Séminaire Guigoz-GENEUP-RP, 29-30 September 1986, Deauville.) Muray Print, Asnières, France. pp. 183-195.

20. Allen, M. C. 1984. Developmental outcome and followup of the small for gestational age infant. Semin. Perinatol. 8:123-156.

21. Vial, M. 1986. Le retard de croissance intra-utérin dans deux maternités parisiennes. Etude rétrospective sur 2 ans. In Retard de Croissance Intra-utérin: Période Anténatale. ( ler Séminaire Guigoz-GENEUP-RP, 29 September 1986, Deauville.) Muray Print, Asnières, France. pp. 87-98.

22. Lejeune, C., I. Thizon-De Gaulle, and J. M. Retbi. 1992. Problèmes cliniques posés par le nouveau-né atteint de retard de croissance intra-utérin (RCIU). In Journées Parisiennes de Pédiatrie, Flammarion Médecine-Sciences, Paris. pp. 49-56.

23. Chatelain, P., M. Deiber, and B. Salle. 1986. Facteurs de la croissance foetale: physiologie et physiopathologie dans le retard de croissance intra-utérin. In Retard de Croissance Intra-utérin: Période Anténatale. ( ler Séminaire Guigoz-GENEUP-RP, 29-30 September 1986, Deauville.) Muray Print, Asnières, France. pp. $15-20$

24. Naeye, R. L. 1992. Fetal growth. In Disorders of the Placenta, Fetus, and Neonate. Diagnosis and Clinical Significance. Mosby-Year Book, Inc., Littleton, MA. pp. 41-76.

25. Leroy, B., and F. Lefort. 1971. A propos du poids et de la taille des nouveaux-nés a la naissance. Rev. Fr. Gynecol. Obstet. 66:391-396.

26. Benirschke, K., and P. Kaufmann. 1990. In Pathology of the human placenta. 2nd ed. Springer-Verlag New York Inc., New York. 870 pp.

27. Alsat, E., Y. Bouali, S. Goldstein, A. Malassiné, M. H. Laudat, and L. Cedard. 1982. Characterization of specific low-density lipoprotein binding sites in human term placental microvillous membranes. Mol. Cell. Endocrinol. 28:439-453.
28. Udenfriend, S., S. Stein, P. Bohlen, and W. Dairman. 1972. Fluorescamine: a reagent assay of aminoacid, peptides, proteins, and primary amines in picomole range. Science (Wash. DC). 178:871-872.

29. Laemmli, U. K. 1970. Cleavage of structural proteins during the assembly of the head of bacteriophage T4. Nature (Lond.). 227:680-685

30. Lowe, W. L., F. T. Boyd, D. W. Clarke, M. K. Raizada, C. Hart, and D. Le Roy. 1986. Development of brain insulin receptors: structural and functiona studies of insulin receptors from whole brain and primary cell cultures. Endocrinology. 119:25-35.

31. Honegger, A. M., T. Dull, D. Szapary, A. Komoriya, R. Kris, A. Ullrich, and J. Schlessinger. 1988. Kinetic parameters of the protein tyrosine kinase activity of EGF-receptor mutants with individually altered autophosphorylation sites. EMBO (Eur. Mol. Biol. Organ.) J. 7:3053-3060.

32. Scatchard, G. 1947. The attraction of proteins for small molecules and ins. Ann. NY Acad. Sci. 51:660-672.

33. Rosenthal, H. E. 1967. A graphic method for the determination and presentation of binding parameters in a complex system. Anal. Biochem. 20:525532.

34. Massagué, J. 1987. Identification of receptor proteins for type-alpha transforming growth factor. Methods Enzymol. 146:143-153.

35. Valentine-Braun, K. A., M.-D. Hollenberg, E. Fraser, and J. K. Northup. 1987. Isolation of a major human placental substrate for epidermal growth factor receptor kinase: immunological cross-reactivity with transducine and sequence homology with lipocortine. Arch. Biochem. Biophys. 259:262-282.

36. Sheets, E. E., T. D. Giugni, G. G. Coates, D. D. Schlaepfer, and H. T. Haigler. 1987. EGF dependent phosphorylation of a 35 -kilodalton protein in placental membranes. Biochemistry. 26:1164-1172.

37. Kris, R. M., I. Lax, W. Gullick, M. D. Waterfield, A. Ullrich, M. Friedkin, and J. Schlessinger. 1985. Antibodies against a synthetic peptide as a probe for the kinase activity of the avian EGF receptor and v-erbB protein. Cell. 40:619-625.

38. Evain-Brion, D. 1990. Growth factors and trophoblast differentiation. In Placental Communications: Biochemical, Morphological and Cellular aspects. $\mathrm{L}$. Cedard, E. Alsat, J. C. Challier, G. Chaouat, and A. Malassiné, editors. Colloques Institut National de la Santé et de la Recherche Médicale, John Libbey Eurotext, Montrouge, France 199:91-97.

39. Chernoff, J., A. R. Schievella, C. A. Jost, R. L. Erikson, and B. G. Neel. 1990. Cloning of a cDNA for a major human protein-tyrosine-phosphatase. Proc Natl. Acad. Sci. USA. 87:2735-2739.

40. Tonks, N. K., and H. Charbonneau. 1989. Protein tyrosine dephosphorylation and signal transduction. TIBS (Trends Biochem. Sci.). 14:497-500.

41. Chinkers, M., and J. S. Brugge. 1984. Characterization of structural domains of the human epidermal growth factor receptor obtained by partial proteolysis. J. Biol. Chem. 259:11534-11542.

42. Hofmann, G. E., Ch. V. Rao, F. R. Carman, Jr., and T. A. Siddiqi. 1988 ${ }^{125}$ I-Human epidermal growth factor specific binding to placentas and fetal membranes from various pregnancy states. Acta Endocrinol. (Copenh). 117:485-490.

43. Sunhara, G. I., K. G. Nelson, T. K. Wong, and G. W. Lucier. 1987 Decreased human birth weights after in utero exposure to PCBs and PCDFs are associated with decreased placental EGF-stimulated receptor autophosphorylation capacity. Mol. Pharmacol. 323:572-578.

44. Guyda, H., L. Mathieu, W. Lei, D. Manchester, S.-L. Wang, S. Ogilvie, and K. T. Shiverick. 1989. Benzo(a)pyrene inhibits epidermal growth factor binding and receptor autophosphorylation in human placental cell cultures. $\mathrm{Mol}$. Pharmacol. 37:137-143.

45. Schlessinger, J. 1986. Allosteric regulation of the epidermal growth factor receptor kinase. J. Cell. Biol. 103:2067-2072.

46. Riedel, H., T. J. Dull, A. M. Honegger, J. Schlessinger, and A. Ullrich. 1989. Cytoplasmic domains determine signal specificity, cellular routing characteristics and influence ligand binding of epidermal growth factor and insulin receptors. EMBO (Eur. Mol. Biol. Organ.) J. 8:2943-2953.

47. Nessmann-Emmanuelli, C., G. Sturbois, B. Kone-Pale, J. Goujard, G. Breart, C. Sureau, and F. Lepage. 1976. Examen macroscopique du placenta frais. Analyse statistique de 1200 cas. Confrontation avec la pathologie maternelle et néo-natale. J. Gynecol. Obstet. Biol. Reprod. 5:397-406.

48. Nessmann-Emmanuelli, C., G. Breart, B. Kone-Pale, G. Sturbois, J. Goujard, C. Sureau, and F. Lepage. 1978. Correlations entre la pathologie placentaire et les pathologies maternelles et néonatales. J. Gynecol. Obstet. Biol. Reprod. 7:933-944.

49. Althabe, O., and C. Labarrere. 1985. Chronic villitis of unknown aetiology and intrauterine growth-retardated infants of normal and low ponderal index. Placenta. 6:369-373.

50. Fondacci, C. A.-L. Delezoide, C. Nessmann. 1992. Intérêt de l'examen foetoplacentaire dans les retards de croissance intra-utérins ( RCIU). In Journées Parisiennes de Pédiatrie. Flammarion Médecine-Sciences, Paris. pp. 57-61.

51. Pijnenborg, J. 1988. Establishment of uteroplacental circulation. Reprod. Nutr. Dev. 28(6B):1581-1586.

52. Zhou, Y., C. H. Damsky, K. Chiu, J. M. Roberts, and S. J. Fisher. 1993. Preeclampsia is associated with abnormal expression of adhesion molecules by invasive cytotrophoblasts. J. Clin. Invest. 91:950-960. 